\title{
Erosion of topsoil decreases the yield and nutrient uptake of maize and soybean grown in Mollisols
}

\author{
Lili Guo ${ }^{1}$, Yue Yang ${ }^{1}$, yue zhao ${ }^{1}$, Yansheng $\mathrm{Li}^{2}$, yueyu sui ${ }^{1}$, Caixian Tang ${ }^{3}$, Jian $\mathrm{Jin}^{1}$, and \\ Xiaobing $\mathrm{Liu}^{1}$ \\ ${ }^{1}$ Northeast Institute of Geography and Agroecology Chinese Academy of Sciences \\ ${ }^{2}$ Northeast Institute of Geography and Agroecology, Chinese Academy of Sciences \\ ${ }^{3}$ La Trobe University
}

May 18, 2020

\begin{abstract}
We established three simulated erosion severities with topsoil depths of 10, 20 and $30 \mathrm{~cm}$ in a Mollisol farmland under a maizesoybean rotation system with no-tillage. After three consecutive years of field experiment, the decrease in topsoil thickness from 30 to $10 \mathrm{~cm}$ resulted in $9-22 \%$ of decrease in maize yield but not soybean. Compared to the 30 and 20-cm topsoil thickness, the 10-cm topsoil significantly lowered root and shoot biomass of maize at the jointing (V7) and milk stages (R3) and of soybean at the mid-seed filling stage (R6). Compared to the 30-cm topsoil, the 10-cm topsoil decreased available nitrogen and phosphorus in soil by $42 \%$ and $36 \%$ under maize, and by $25 \%$ and $19 \%$ under soybean, respectively, while the shallow topsoil also decreased $\mathrm{N}, \mathrm{P}$ and $\mathrm{K}$ uptake per unit root length with the decreases being less for maize than soybean. Compared to the 30-cm topsoil, the $10-\mathrm{cm}$ and $20-\mathrm{cm}$ topsoil significantly increased the activities of urease, phosphatase and invertase in maize-grown soil, but not in soybean-grown soil except for the activity of urease in 10-cm topsoil. Maize was more sensitive to soil erosion than soybean due to the greater decreases in soil nutrient availability and its capability of nutrient uptake. The greater stimulation of nutrient mineralization processes in soil did not alleviate the nutrient constraint to maize yield under severe erosion conditions.
\end{abstract}

\begin{abstract}
Soil erosion decreases topsoil depth, and hence soil fertility and crop productivity in agricultural systems. However, it is not clearly elucidated how different crop species adapt to the soil erosion regarding root function, nutrient uptake and rhizosphere biochemical properties, which is pivotal to cropping strategy under soil erosion. We established three simulated erosion severities with topsoil depths of 10, 20 and 30 $\mathrm{cm}$ in a Mollisol farmland under a maize-soybean rotation system with no-tillage. After three consecutive years of field experiment, the decrease in topsoil thickness from 30 to $10 \mathrm{~cm}$ resulted in $9-22 \%$ of decrease in maize yield but not soybean. Compared to the 30 and 20-cm topsoil thickness, the 10-cm topsoil significantly lowered root and shoot biomass of maize at the jointing (V7) and milk stages (R3) and of soybean at the mid-seed filling stage (R6). Compared to the 30-cm topsoil, the 10-cm topsoil decreased available nitrogen and phosphorus in soil by $42 \%$ and $36 \%$ under maize, and by $25 \%$ and $19 \%$ under soybean, respectively, while the shallow topsoil also decreased $\mathrm{N}, \mathrm{P}$ and $\mathrm{K}$ uptake per unit root length with the decreases being less for maize than soybean. Compared to the $30-\mathrm{cm}$ topsoil, the $10-\mathrm{cm}$ and $20-\mathrm{cm}$ topsoil significantly increased the activities of urease, phosphatase and invertase in maize-grown soil, but not in soybean-grown soil except for the activity of urease in 10-cm topsoil. Maize was more sensitive to soil erosion than soybean due to the greater decreases in soil nutrient availability and its capability of nutrient uptake. The greater stimulation of nutrient mineralization processes in soil did not alleviate the nutrient constraint to maize yield under severe erosion conditions.
\end{abstract}


Key words : soil erosion; topsoil depth; black soil; soil enzymes

\section{Introduction}

It is estimated that $15.1 \%$ of global land suffers degradation, of which $83.6 \%$ results from soil erosion (Lal, 2001; Gao et al., 2015). Soil erosion is a gradual process of removal, transport and deposition of topsoil caused by wind and water (Liu et al., 2010). The reduction of topsoil thickness is one of significant impacts of erosion on farmland. Topsoil thickness is a major indicator of soil quality and productivity (Sui et al., 2013). The reduction of topsoil thickness worsens soil physical, chemical and biological properties, and thus reduces crop productivity (Christensen and McElyea, 1988; Larney et al., 2000; Sarapatka et al., 2018). Therefore, preventing soil erosion and understanding the response of crop yields to the erosion is important in assessing the vulnerability of agriculture to erosion (Lal et al., 2000; Bakker et al., 2004).

It is difficult to establish the relationship of soil erosion and crop productivity as the process of degradation is slow (Bakker et al., 2004; Zhou et al., 2015). Previous studies have been conducted to assess the effects of soil erosion on crop productivity through artificial erosion approaches such as cut-and-fill experiments (Larney et al., 2000; Jagadamma et al., 2009), transects characterized by different erosion phases (Kosmas et al., 2001; Rejman and Iglik, 2010) and variable past erosions (Graveel et al., 2002; Fenton et al., 2005). Furthermore, simulation modeling has been established to estimate the long-term effect of soil erosion on plant growth (Pierce et al., 1983; Duan et al., 2016). For instance, Wang et al. (2009) demonstrated that soybean yield was exponentially decreased with increasing soil erosion depth due to the loss of soil organic matter and nutrients using the Agriculture Land Management Alternatives with Numerical Assessment Criteria (ALMANAC) model. However, these researches did not clarify the relationship of soil erosion and crop productivity, which may exhibit linear, concave and convex response curves (Bakker et al., 2004). Besides different experimental methods, the response of crop yield to soil erosion also depends on variables such as crop type, soil properties, management practices and climate characteristics (Bakker et al., 2007).

The negative effects of soil erosion on crop productivity can be attributed to the loss of soil organic carbon and plant nutrients, especially nitrogen $(\mathrm{N})$, phosphorous $(\mathrm{P})$, and potassium $(\mathrm{K})$ (Kaspar et al., 2004; Herbrich et al., 2018). Quinton et al. (2010) reported that topsoil erosion decreased 23-42 Tg of nitrogen, 2.1-3.9 $\mathrm{Tg}$ of organic $\mathrm{P}$ and 12.5-22.5 Tg of inorganic P per year on the global scale. Plants obtain nutrients from soil mainly through roots; however, root growth in the soil vary with soil physical, chemical, and biological properties (Wang et al., 2015; Shinohara et al., 2016; Herbrich et al., 2018). It has been reported that a reduction of topsoil thickness caused by soil erosion results in decreases in soil organic matter (Liu et al., 2003; Srinivasan et al., 2012; Li et al., 2019a; Miao et al., 2019), available nutrients (Bakker et al., 2004; Sui et al., 2013; Xiong et al., 2018) and the effective rooting zone (Graveel et al., 2002). In addition, soil enzymes play an important role in soil quality and soil nutrient availability to plants (Jia et al., 2005; Stott et al., 2010; Sarapatka et al., 2018). Researchers have used soil enzyme activities as indicators of soil deterioration caused by erosion (Chaer et al., 2009; Sui et al., 2013; Nosrati, 2013). However, there are limited studies on nutrients uptake of crop and activities of enzymes as affected under zero tillage and residue cover in the eroded areas of China (Sui et al., 2013).

As an important grain production area, northeast China produces $18.7 \%$ of China's total grains of which $45 \%$ and $33 \%$ are soybean, and maize, respectively (National Bureau of Statistics of China, 2012). However, soil erosion increasingly becomes a major limiting factor for productivity of agricultural land in this region (Liu et al., 2010). Zhang et al. (2008) showed that the average thickness of topsoil layer decreased from $43.7 \mathrm{~cm}$ in 1982 to less than $30 \mathrm{~cm}$ in 2002 . Sui et al. (2009) reported that the yield reduction in maize and soybean were $13 \%$ and $9 \%$ for the removal of every $10-\mathrm{cm}$ topsoil. A survey with soil erosion in cropland in northeastern China over the past 300-year history conducted by Xie et al. (2019) showed that the soil loss of cropland exponentially increased due to the increasing cropland acreage in the steep slope areas.

In this study, we constructed three levels of topsoil depth in a Mollisol with the same physical, chemical and biological properties to explore how maize and soybean responded to topsoil erosion under zero tillage,

residue cover and maize-soybean rotation conditions. The objectives were (1) to quantify the influence of 
topsoil thickness on crop yield; (2) to compare nutrient uptake of crops under three topsoil depths; (3) to analyze the effect of topsoil thickness on root development and biochemical characteristics in the rhizosphere of the crop plants.

\section{Materials and methods}

\subsection{Experimental design}

A field experiment was established in 2015 in a farming field (47 $53^{\prime}$ N, 153deg33' E), Heilongjiang Province, northeast China. The soil was a typical Mollisol with glacial parent material. The field site had 40 years of cultivation history with a $5 \mathrm{deg}$ slope and $30 \mathrm{~cm}$ of A horizon. The annual average temperature in the region is $1.5 \mathrm{deg} \mathrm{C}$, ranging from $-37 \mathrm{deg} \mathrm{C}$ in the winter to $32 \mathrm{deg} \mathrm{C}$ in the summer. The average temperature is $18.1 \mathrm{degC}$ and rainfall during the growing season (from May to September) $424 \mathrm{~mm}$.

The experiment deployed a split-block design with three simulated topsoil depths $(10,20$ and $30 \mathrm{~cm})$ as the main plot and crop species (maize and soybean) as sub-plot treatments. Each treatment had three replicates. Each plot had an area of $10.4 \mathrm{~m} \times 7.5 \mathrm{~m}$. We first removed all topsoil of experiment plots, mixed, and then back-filled up to 10, 20 and $30 \mathrm{~cm}$ in depth with a bulk density of $1.1 \mathrm{~g} \mathrm{~cm}^{-3}$. As the average depth of topsoil in the Mollisol region is $32.7 \mathrm{~cm}$, this study treated the topsoil depth of $30 \mathrm{~cm}$ as the control, and 10-cm and 20-cm topsoil depths as erosion treatments. The reconstructed soil layer was naturally incubated for one year. Maize and soybean crops were grown in a rotation module, in which both maize and soybean were grown in the same season. Zero-tillage was deployed. The maize and soybean stalks were returned to the surface of field plots after harvesting.

Maize (Zea mays L. cv. Xinggen 5) and soybean (Glycine max(L.) Merr. cv. Dongsheng 1) were sown in early May 2016, 2017 and 2018. For maize, $150 \mathrm{~kg} \mathrm{ha}^{-1}$ of diammonium phosphate, $75 \mathrm{~kg} \mathrm{ha}^{-1}$ of urea, and $50 \mathrm{~kg} \mathrm{ha}^{-1}$ of potassium sulfate were applied before sowing, and $225 \mathrm{~kg} \mathrm{ha}^{-1}$ of urea was applied at the five-leaf collar (V5) stage. For soybean, the fertilizer application rates were $150 \mathrm{~kg} \mathrm{ha}^{-1}, 50 \mathrm{~kg} \mathrm{ha}{ }^{-1}$ and 50 $\mathrm{kg} \mathrm{ha}^{-1}$ for diammonium phosphate, urea and potassium sulfate, respectively. Sowing rates were 5 and 25 seeds $\mathrm{m}^{-2}$ for maize and soybean, respectively. Maize plants were harvested at the jointing stage (V7) and milk stages (R3), and soybean plants were at the initial flowering (R1) and mid-seed-filling stage (R6).

\subsection{Measurements}

\subsubsection{Biomass and seed yield}

At each harvest, we randomly selected thirty plants of maize and soybean in each plot. The aboveground was cut and separated into leaves and stem. All plant samples were oven-dried at 105degC for 30 min and then $80 \mathrm{deg} \mathrm{C}$ for $72 \mathrm{~h}$. In each plot, root samples were taken at three locations of each plot, i.e. top, middle and down sides of the plot with a root sampler $(8 \mathrm{~cm}$ of diameter $\mathrm{x} 10 \mathrm{~cm}$ of depth) to sample roots up to 30 $\mathrm{cm}$ of soil depth at each location. The root samples were washed with tap water until free of soil, and were placed in a plexiglass tray with $4 \mathrm{~mm}$ of clean water in depth. Total root length, surface area and diameter were analyzed with the Win-RHIZO 2004 (Regent Instruments, Quebec, Canada) (Costa et al., 2002; Jin et al., 2012). After scanning, root samples were oven-dried to determine dry weight.

At the full maturity, two central rows of each plot were hand-harvested for yield estimation in 2016, 2017 and 2018. Grain yield was adjusted to $130 \mathrm{~g} \mathrm{~kg}^{-1}$ moisture content.

\subsubsection{Plants nutrient analysis}

Plant simples were ground using a ball mill (Retsol MM2000, Retsch, Haan, Germany). Subsamples of shoots and roots were digested with a mixture of nitric and perchloric acid (4:1) (Jin et al., 2012). The concentrations of $\mathrm{K}$ in the digest solution was determined with a flame photometer (Liu et al., 2020). The $\mathrm{P}$ concentration were measured by SKALAR $\mathrm{San}^{++}$continuous flowing analyzer after acidic digestion $(\mathrm{Xu}$ et al., 2018). The concentrations of $\mathrm{N}$ in plant tissues were determined using an Elementar CNS analyser (Vario EL III, Elementar Analysensysteme GmbH, Germany) (Li et al., 2019b). 


\subsubsection{Available nutrientsin the rhizosphere}

The rhizosphere soils were collected by shaking the roots and the soil adhering to the roots was considered as rhizosphere soil (Nazih et al., 2001). All soil samples were stored in a refrigerator at $4 \operatorname{deg} \mathrm{C}$ for further analysis.

Soil available $\mathrm{N}\left(\mathrm{NH}_{4}{ }^{+}\right.$and $\left.\mathrm{NO}_{3}{ }^{-}\right)$was determined with the methods described by Miah et al. (1998). Soil Olsen $\mathrm{P}$ was obtained by extraction in $\mathrm{NaHCO}_{3}$ and analyzed by the Mo-Sb colorimetric method (UV2550, Shimadzu, Japan) (Bao, 2000). Available $\mathrm{K}$ was extracted with neutral $1 \mathrm{M} \mathrm{NH}_{4} \mathrm{OAc}$, and $\mathrm{K}$ concentration was measured by a flame photometer (Chen and Gabelman, 1995).

\subsubsection{Enzyme activities in the rhizosphere}

The activities of urease, phosphatase and invertase in rhizosphere soil were determined by indophenol colorimetric method, disodium phenyl phosphate and 3,5-dinitrosalicylic acid colorimetric methods, respectively (Ge et al., 2007).

\subsection{Statistical analysis}

Data were analyses with SPSS 13.0 software (Chicago, IL). Two-way ANOVA was used to determine the effects of topsoil depth, crop type and their interactions on seed yield, crop biomass, nutrient uptake, soil available nutrient and enzyme activity. Treatment means were compared using the Duncan's multiple range test $(P<0.05)$.

\section{Result}

\subsection{Crop yield}

Compared to the 30-cm topsoil depth, maize yield under the 10-cm topsoil depth decreased by $22 \%, 11 \%$ and 9\% in 2016, 2017 and 2018, respectively $(P<0.05$, Fig. 1a). Yield under the 20-cm topsoil depth significantly decreased only in $2016(P<0.05$, Fig. 1a). Soybean yield did not decrease under the $10-\mathrm{cm}$ topsoil depth, compared to the 30-cm topsoil depth. However, the 20 -cm topsoil depth significantly increased yields in 2016 and $2018(P<0.05$, Figs $1 \mathrm{~b} \& \mathrm{~S} 1)$.

\subsection{Root and shoot biomass}

Root biomass of maize under the 10-cm topsoil was $35 \%$ and $10 \%$ lower at V7 and R3, respectively, compared to the 30-cm topsoil depth $(P<0.05$, Fig. 2a). Similarly, shoot biomass also decreased with the decrease in topsoil depth except for 20 -cm topsoil depth at R3 $(P<0.05)$.

In comparison, root biomass of soybean was significantly increased by $27 \%$ and $34 \%$ under the 20 -cm topsoil depth at R1 and R6, respectively, than under the 30-cm topsoil depth. However, the 20-cm and 10-cm topsoil depths resulted in $27 \%$ and $36 \%$ of decrease in shoot biomass at R6, respectively, compared to $30 \mathrm{~cm}$ topsoil depth $(P<0.05$, Fig. 2d).

\subsection{Nutrient uptake}

In maize, $10 \mathrm{~cm}$ of topsoil depth decreased shoot N, P and K uptake by $13 \%, 15 \%$ and $54 \%$ at V7, respectively, compared to $30 \mathrm{~cm}$ of topsoil depth. There was no difference in the $\mathrm{N}$ and $\mathrm{K}$ uptake between $30 \mathrm{~cm}$ and 20 $\mathrm{cm}$ of topsoil depths. An increase in N, P and K uptake was found under $20 \mathrm{~cm}$ of soil depth compared to $30 \mathrm{~cm}$ of soil depth at R3 $(P<0.05$, Fig. 3$)$.

In soybean, nutrient uptake did not decrease with decreasing topsoil depth at R1 except for shoot K uptake. However, at R6, N, P and K uptake significantly decreased under $20 \mathrm{~cm}$ and $10 \mathrm{~cm}$ of topsoil depth, compared to $30 \mathrm{~cm}$ of topsoil depth $(P<0.05$, Fig. $3 \mathrm{~d}$, e, f $)$.

Root had a similar trend in N, P and K uptake in response to different soil depths (Fig. S1).

\subsection{Specific nutrient uptake rate}


In maize, the $\mathrm{N}, \mathrm{P}$ and $\mathrm{K}$ uptake per unit root length under $10 \mathrm{~cm}$ of topsoil depth significantly decreased by $44 \%, 46 \%$ and $57 \%$ at V7, respectively, compared to $30 \mathrm{~cm}$ of topsoil depths $(P<0.05$, Fig. 4$)$. There was no difference in the $\mathrm{P}$ and $\mathrm{K}$ uptake per unit root length between $30 \mathrm{~cm}$ and $20 \mathrm{~cm}$ of topsoil depths at V7. An increase in the $\mathrm{N}$ and $\mathrm{K}$ uptake per unit root length was found under $20 \mathrm{~cm}$ of topsoil depths compared to $30 \mathrm{~cm}$ of soil depth at R3.

In soybean, the N, P and K uptake per unit root length under $10 \mathrm{~cm}$ of topsoil depth was $46 \%, 42 \%$ and $50 \%$ lower than under $30 \mathrm{~cm}$ of topsoil depths at R1, respectively. The N, P and K uptake was $71 \%, 69 \%$ and $74 \%$ lower under $20 \mathrm{~cm}$ and $53 \%, 45 \%$ and $57 \%$ lower under $10 \mathrm{~cm}$ of topsoil depths than under $30 \mathrm{~cm}$ of topsoil depth at R6, respectively $(P<0.05$, Fig. 4 d, e, f).

The total root length in top 10-cm layer increased with decreasing topsoil depth for maize at V7 and soybean at R1. The total root length was maximum under 20-cm topsoil depth for maize at R3 and soybean at R6 (Fig. S2).

\subsection{Available nutrients in the rhizosphere}

The concentrations of available $\mathrm{N}$ and $\mathrm{P}$ in the rhizosphere of maize were $42 \%$ and $36 \%$ lower, respectively, under the 10-cm than the 30-cm topsoil depth $(P<0.05$, Fig. 5a, b). Topsoil depth did not affect available $\mathrm{K}(P>0.05$, Fig. 5c). In comparison, the concentrations of available $\mathrm{N}$, Olsen $\mathrm{P}$ and available $\mathrm{K}$ in the rhizosphere of soybean were $12 \%, 25 \%$ and $19 \%$ lower under the 10-cm than the $30-\mathrm{cm}$ topsoil depth, respectively $(P<0.05$, Fig. 5a, c). However, there was no difference in concentrations of available N, P and $\mathrm{K}$ between the $30-\mathrm{cm}$ and $20-\mathrm{cm}$ topsoil depths $(P>0.05$, Fig. $5 \mathrm{c})$.

\subsection{Enzyme activities in rhizosphere}

In the rhizosphere of maize, the activities of urease and phosphatase were $21 \%$ and $57 \%$ higher under 20 $\mathrm{cm}$ than $30 \mathrm{~cm}$ of topsoil depth. In addition, decreasing the topsoil depth to $10 \mathrm{~cm}$ further increased the activities of urease, phosphatase and invertase which were $22 \%, 162 \%$ and $14 \%$ higher compared to $30 \mathrm{~cm}$ of topsoil depths.

In soybean rhizosphere, urease activity was by $22 \%$ higher, but phosphatase activity $58 \%$ lower under the $10-\mathrm{cm}$ than the $30-\mathrm{cm}$ topsoil depth. The activities of phosphatases and invertase were $49 \%$ and $19 \%$ lower under $20 \mathrm{~cm}$ than $30 \mathrm{~cm}$ of topsoil depth, respectively $(P<0.05$, Fig. $6 \mathrm{c})$.

\section{Discussion}

Decreasing topsoil thickness decreased the seed yield of maize but not soybean. The great reduction of root and shoot biomass at V7 was associated with the maize yield reduction under shallow topsoil depths compared to thick topsoil (Fig. 2), because biomass production at this growth stage was essential to maize yield formation (Russo et al., 2004; Herrmann et al., 2013). Similarly, Lin et al. (2019) found that there was no difference in soybean yield between "light" and "moderate" erosion sites, but $11 \%$ of yield loss was observed in maize grown in the "moderate" erosion sites. These results demonstrated that the increasing soil erosion reduced crop productivity and the reduction magnitude might be dependent of crop species (Bakker et al., 2007; Gao et al., 2015; Lin et al., 2019).

The decreases in seed yield and biomass with the decrease of topsoil thickness might result from the reduction of nutrient supply in soil (Sanaullah et al., 2012; Bista et al., 2018). Our present study showed that $10 \mathrm{~cm}$ of topsoil depth decreased the N, P and K uptake per unit root length of both maize and soybean expect maize at R3 (Fig. 4). As N, P and K are considered as the most important major nutrients for crop physiological function and production capacity (Wang et al., 2017), this study showed the linear correlations of total and specific nutrient uptake with total shoot biomass production (data not shown).

As soil nutrients are generally mainly distributed in the topsoil (Liu et al., 2013; Zhao et al., 2016), the decrease of topsoil thickness also decreased root nutrient acquisition. It was evident that nutrient uptake per unit root length of both crops was lower in $10 \mathrm{~cm}$ than $30 \mathrm{~cm}$ of topsoil depth at both vegetative and reproductive stages. Zobisch et al. (1995) reported that 3-6 t ha-1 loss of topsoil resulted in $24 \%$ and $28 \%$ 
of decreases in $\mathrm{P}$ and $\mathrm{K}$ uptake in maize, and $15 \%$ and $16 \%$ in beans. In addition, soil erosion reduced soil ammonium concentration by $66 \%$ at the Loess Plateau (Zheng et al., 2005), and soil organic C, total $\mathrm{N}$ and total $\mathrm{P}$ by $33 \%, 28 \%$ and $27 \%$, respectively, at an alpine grassland (Nie et al., 2013). In this study, the decrease of the topsoil depth resulted in the substantial decreases in plant $\mathrm{N}$ and $\mathrm{P}$ uptake, and decreases in the available $\mathrm{N}$ and Olsen $\mathrm{P}$ concentrations in rhizosphere soil as well, but not much in available K. Our results indicated that the impact of the soil erosion on $\mathrm{N}$ and $\mathrm{P}$ cycles would constrain the crop productivity (Fig. 5). The stimulation of the urease, phosphatase and invertase activities in the rhizosphere of maize (Fig. 6) also indicated the scares of $\mathrm{N}$ and $\mathrm{P}$ availability to plants drove the biochemical processes of the $\mathrm{N}$ and $\mathrm{P}$ mineralization. In comparison, soybean yield did not respond to the decrease of topsoil thickness in this study. Similarly, Sui et al. (2009) found that soybean yield did not decrease by the removal of $5 \mathrm{~cm}$ topsoil, which had decreased maize yield by $10 \%$ in a black soil. It appeared that maize was more sensitive to topsoil erosion than soybean, which could be attributed to various capabilities of nutrient acquisition between crops. Nitrogen uptake per unit root length of maize was dramatically decreased at V7 than soybean at R1 under $10 \mathrm{~cm}$ of topsoil depth in comparison to $30 \mathrm{~cm}$. This also implied that soybean plants were capable of fixing $\mathrm{N}_{2}$ particularly when soil $\mathrm{N}$ fertility decreased due to the erosion/removal of fertile topsoil. In terms of $\mathrm{P}$ uptake, $\mathrm{P}$ availability under $10 \mathrm{~cm}$ of topsoil might not meet the nutrient demand of maize as low availability of $\mathrm{P}$ in the rhizosphere of maize and stronger phosphatase activity which can mineralize soil organic P for maize plants (Fig. 6). However, it did not occur in the rhizosphere of soybean. Some studies had found that soybean not only alleviated $\mathrm{N}$ deficiency due to $\mathrm{N}_{2}$-fixation (Li et al., 2017), but also had less $\mathrm{P}$ limitation than non-leguminous crops which had resulted from rhizosphere acidification during $\mathrm{N}_{2}$ fixation to mobilize the non-labile $\mathrm{P}$ ( $\mathrm{Li}$ et al., 2019b). Although low concentrations of available nutrients could stimulate enzymatic catalysis, mineralized nutrients might not sufficiently mitigate nutrient constraints to maize under erosion (Berhe et al., 2012). Since the quantity of enzymes is largely determined by microbial activity and the content of soil organic matter (Wang et al., 2012; Nie et al., 2015), further study is needed to understand how the soil microorganisms mineralize soil organic matter under topsoil erosion, considering $\mathrm{C}$ input and soil nutrient supply in the maize-soybean rotation system.5. ConclusionIncreasing topsoil erosion decreased yield of maize more severely than soybean. The deficiencies of $\mathrm{N}$ and $\mathrm{P}$ in maize under soil erosion might greatly constrain the productivity even though the nutrient mineralization was stimulated. Soybean was more resilient to topsoil erosion than maize. Increasing $\mathrm{N}$ and $\mathrm{P}$ supply would be applicable to alleviate yield loss of maize grown in eroded soils.Acknowledgement: This research was partially funded by the National Key R\&D Program of China [2017YFC0504200; 2017YFD0300300], the National Natural Science Foundation of China [41671274], and partially supported by the Professional Association of the Alliance of International Science Organizations (grant number ANSO-PA-2020-12).

\section{Captions}

Fig. 1. Effect of topsoil depth on grain yields of maize and soybean in 2016, 2017 and 2018. The main effects of topsoil depth, crop species and cropping year, and their interactions are all highly significant $(P<$ $0.001)$. Values with means +- standard error $(n=3)$. Within a growing season of each panel, values with a same letter are not significantly different $(P>0.05)$.

Fig. 2. Effect of topsoil depth on root and shoot biomass of maize at the jointing (V7) and milk (R3) stages, and of soybean at the initial flowering (R1) and seed-filling (R6) stages in 2017. Values with means + - standard error $(\mathrm{n}=3)$. Within a growth stage of each panel, values with a same letter are not significantly different $(P>0.05)$.

Fig. 3. Effect of topsoil depth on $\mathrm{N}, \mathrm{P}$ and $\mathrm{K}$ uptake in shoot of maize at the jointing (V7) and milk (R3) stages, and of soybean at the initial flowering (R1) and seed-filling (R6) stages in 2017. Values with means +- standard error $(\mathrm{n}=3)$. Within a growth stage of each panel, values with a same letter are not significantly different at $(P>0.05)$.

Fig. 4. Effect of topsoil depth on N, P and K uptake per unit root length of maize at the jointing (V7) and milk (R3) stages, and of soybean at the initial flowering (R1) and seed-filling (R6) stages in 2017. Values with means +- standard error $(n=3)$. Within a growth stage of each panel, values with a same letter are not 
significantly different at $(P>0.05)$.

Fig. 5. Effect of topsoil depth on the concentrations of available N, P and $\mathrm{K}$ in the rhizosphere soil of maize at the milk stage (R3), and of soybean at the seed-filling stage (R6) in 2017. Values with means +- standard error $(\mathrm{n}=3)$. Within each panel, values with a same letter are not significantly different at $P>0.05$ among treatments in two crops (2-way ANOVA).

Fig. 6. Effect of topsoil depth on enzyme activities in the rhizosphere of maize at the milk stage (R3), and of soybean at the seed-filling stage (R6) in 2017. Values with means +- standard error $(n=3)$. Within each panel, values with a same letter are not significantly different at $P>0.05$ among treatments in two crops (2-way ANOVA).

Table 1. Significant level $(P)$ of main effects and interactions of topsoil depth and crop species on grain yield $(2016,2017,2018)$, growth parameters (2017), nutrient uptake (2017), and concentrations of available nutrients (N, P and K) and activities of enzymes in the rhizosphere soil (2017) of maize at the jointing (V7) and milk (R3) stages, and of soybean at the initial flowering (R1) and seed-filling (R6) stages.

Fig. S1. Effect of topsoil depth on N, P and K uptake in root of maize at the jointing (V7) and milk (R3) stages, and of soybean at the initial flowering (R1) and seed-filling (R6) stages in 2017. Values with means + - standard error $(\mathrm{n}=3)$. Within a growth stage of each panel, values with a same letter are not significantly different $(P>0.05)$.

Fig. S2. Effect of topsoil depth on total root length of maize at the jointing (V7) and milk (R3) stages, and of soybean at the initial flowering (R1) and seed-filling (R6) stages in the top $30 \mathrm{~cm}$ of soil profile in 2017. Values with means +- standard error $(n=3)$. Within a growth stage of each panel, values with a same letter are not significantly different $(P>0.05)$.

Table S1. The effect of topsoil depth on the concentrations of N, P and K in root, stem and leaves of maize at the jointing (V7) and milk (R3) stages, and of soybean at the initial flowering (R1) and seed-filling (R6) stages in 2017. Values with means +- standard error $(\mathrm{n}=3)$. Values with a same letter are not significantly different between topsoil depths $(P>0.05)$.

\section{References}

Bakker, M. M., Govers, G., Jones, R. A., \& Rounsevell, M. D. A. (2004). The crop productivity-erosion relationship: an analysis based on experimental work. Catena , 57, 55-76.

Bakker, M. M., Govers, G., Jones, R. A., \& Rounsevell, M. D. A. (2007). The effect of soil erosion on Europe's crop yields. Ecosystems,10, 1209-1219.

Bao, S. D. (2000). Soil and agricultural chemistry analysis.Chinese Agriculture Press, Beijing , 263-270.

Berhe, A. A., Harden, J. W., Torn, M. S., Kleber, M., Burton, S. D., \& Harte, J. (2012). Persistence of soil organic matter in eroding versus depositional landform positions. Journal of Geophysical Research , 117, G02019.

Bista, D. R., Heckathorn, S. A., Jayawardena, D. M., Mishra, S., \& Boldt, J. K. (2018). Effects of drought on nutrient uptake and the levels of nutrient-uptake proteins in roots of drought-sensitive and -tolerant grasses.Plants , 7, 1-16.

Chaer, G. M., Myrold, D. D., Bottomley, \& P. J. (2009). A soil quality index based on the equilibrium between soil organic matter and biochemical properties of undisturbed coniferous forest soils of the Pacific Northwest. Soil Biology and Biochemistry, 41, 822-830.

Chen, J. J., \& Gabelman, W. H. (1995). Isolation of tomato strains varying in potassium acquisition using a sand-zeolite culture system. Plant and Soil , 176, 65-70.

Christensen, L. A., \& McElyea, D. E. (1988). Toward a general method of estimating productivity-soil depth response relationships. Journal of Soil and Water Conservation , 43, 199-202. 
Costa, C., Dwyer, L. M., Zhou, X. M., Dutilleul, P., Hamel, C., Reid, L. M., \& Smith D. L. (2002). Root morphology of contrasting maize genotypes. Agronomy Journal , 94, 96-101.

Duan, X. W., Liu, X. B., Gu, Z., Rong, L., \& Feng, D. (2016). Quantifying soil erosion effects on soil productivity in the dry-hot valley, Southwestern China. Environmental Earth Sciences , 75, 1164.

Fenton, T., Kazemi, M., \& Lauterbach-Barrett, M. (2005). Erosional impact on organic matter content and productivity of selected Iowa soils. Soil \& Tillage Research , 81, 163-171.

Gao, X. F., Xie, Y., Liu, G., Liu, B. Y., \& Duan, X. W. (2015). Effects of soil erosion on soybean yield as estimated by simulating gradually eroded soil profiles.Soil ETillage Research , 145, 126-134.

Ge, F. L., Zhang, J. H., Su, Z. A., \& Nie, X. J. (2007). Response of changes in soil nutrients to soil erosion on a purple soil of cultivated sloping land. Acta Ecologica Sinica, 27, 459-464.

Graveel, J. G., Tyler, D. D., Jones, J. R., \& McFee, W. W. (2002). Crop yield and rooting as affected by fragipan depth in loess soils in the southeast USA. Soil ET Tillage Research , 68, 153-161.

Herbrich, M., Gerke, H. H., \& Sommer, M. (2018). Root development of winter wheat in erosion-affected soils depending on the position in a hummocky ground moraine soil landscape. Journal of Soil Science and Plant Nutrition, 181, 147-157.

Herrmann, A., Sieling, K., Wienforth, B., \& Taube, F. (2013). Short-term effects of biogas residue application on yield performance and $\mathrm{N}$ balance parameters of maize in different cropping systems. Journal of Agricultural Science, 151, 449-462.

Jagadamma, S., Lal, R., \& Rimal, B. K. (2009). Effects of topsoil depth and soil amendments on corn yield and properties of two alfisols in Central Ohio. Journal of Soil and Water Conservation , 64, 70-80.

Jia, G., Cao, J., Wang, C., \& Wang, G. (2005). Microbial biomass and nutrients in soil at the different stages of secondary forest succession in Ziwulin, northwest China. Forest Ecology and Management, 217, $117-125$.

Jin, J., Tang, C. X., Armstrong, R., \& Sale, P. (2012). Phosphorus supply enhances the response of legumes to elevated $\mathrm{CO}_{2}$ (FACE) in a phosphorus-deficient Vertisol. Plant and Soil , 358, 91-104.

Kaspar, T. C., Pulido, D. J., Fenton, T. E., Colvin, T. S., Karlen, D. L., Jaynes, D. B., \& Meek, D. W. (2004). Relationship of corn and soybean yield to soil and terrain properties. Agronomy Journal , 96, 700-709.

Kosmas, C., Gerontidis, S., Marathianou, M., Detsis, B., Zafiriou, T., Nan, M. W., Govers, G., Quine, T., \& Vanoost, K. (2001). The effects of tillage displaced soil on soil properties and wheat biomass. Soil E Tillage Research , 58, 31-44.

Lal, R. (2001). Soil degradation by erosion. Land Degradation \& Development, 12, 519-539.

Lal, R., Ahmadi, M., \& Bajracharya, R. M. (2000). Erosional impacts on soil properties and corn yield on Alfisols in Central Ohio. Land Degradation \& $\&$ Development, 11, 575-585.

Larney, F. J., Janzen, H. H., Olson, B. M., \& Lindwall, C. W. (2000). Soil quality and productivity responses to simulated erosion and restorative amendments. Canadian Journal of Soil Science, , 80, 515-522.

Li, T., Zhang, H. C., Wang, X. Y., Cheng, S. L., Fang, H. J., Liu, G., \& Yuan, W. P. (2019a). Soil erosion affects variations of soil organic carbon and soil respiration along a slope in Northeast China.Ecological Processes, 8, 1-10.

Li, Y. S., Yu, Z. H., Liu, X. B., Mathesius, U., Wang, G. H., Tang, C. X., Wu, J. J., Liu, J. D., Zhang, S. Q., \& Jin, J. (2017). Elevated $\mathrm{CO}_{2}$ increases nitrogen fixation at the reproductive phase contributing to various yield responses of soybean cultivars.Frontiers in Plant Science, 8, 1546. 
Li, Y. S., Yu, Z. H., Yang, S. C., Wang, G. H., Liu, X. B., Wang, C. Y., Xie, Z. H., \& Jin, J. (2019b). Impact of elevated $\mathrm{CO}_{2}$ on C: N: P ratio among soybean cultivars. Science of the Total Environment, 694, 133784.

Lin, H. H., Xie, Y., Liu, G., Zhai, J. R., \& Li, S. (2019). Soybean and maize simulation under different degrees of soil erosion. Field Crops Research , 230, 1-10.

Liu, C. K., Wang, X., Tu, B. J., Li, Y. S., Liu, X. B., Zhang, Q. Y., \& Herbert, S. J. (2020). Dry matter partitioning and $\mathrm{K}$ distribution of vegetable soybean genotypes with higher potassium efficiency.Archives of Agronomy and Soil Science, 66, 1-14.

Liu, X. B., Han, X. Z., Song, C. Y., Herbert, S. J., \& Xing, B. S. (2003). Soil organic carbon dynamics in black soils of china under different agricultural management systems. Communications in Soil Science and Plant Analysis , 34, 7-8, 973-984.

Liu, X. B., Zhang, X. Y., Sui, Y. Y., Wang, Y. X., \& Herbert, S. J. (2010). Soil degradation: a problem threatening the sustainable development of agriculture in Northeast China. Plant Soil and Environment, $56,87-97$.

Liu, Z. P., Shao, M. A., \& Wang, Y. Q. (2013). Spatial patterns of soil total nitrogen and soil total phosphorus across the entire Loess Plateau region of China. Geoderma , 197, 67-78.

Miah, M.Y., Kanazawa, S., \& Chino, M. (1998). Nutrient distribution across wheat rhizosphere with oxamide and ammonium sulfate as N source.Soil Science and Plant Nutrition , 44, 579-587.

Miao, S. J., Qiao, Y. F., Yin, Y. F., Jin, J., Martin, B., Liu, X. B., \& Tang, C. X. (2019). Ten-year application of cattle manure contributes to the build-up of soil organic matter in eroded Mollisols. $J$ ournal of Soils and Sediments , 19, 3035-3043.

National Bureau of Statistics of China, (2012). China Statistical Yearbook. China Statistics Press, Beijing , China 479 (In Chinese).

Nazih, N., Finlay-Moore, O., Hartel, G. P., \& Fuhrmann, J. (2001). Whole soil fatty acid methyl ester (FAME) profiles of early soybean rhizosphere as affected by temperature and matric water potential.Soil Biology and Biochemistry , 33, 693-696.

Nie, X. J., Zhang, J. H., \& Gao, H. (2015). Soil enzyme activities on eroded slopes in the sichuan basin, China. Pedosphere, 25, 489-500.

Nie, X. J., Zhao, J. H., \& Qiao, X. N. (2013). Impacts of soil erosion on organic carbon and nutrient dynamics in an alpine grassland soil.Journal of Soil Science and Plant Nutrition 59, 660-668.

Nosrati. K. (2013). Assessing soil quality indicator under different land use and soil erosion using multivariate statistical techniques.Environmental Monitoring Assessment , 185, 2895-2907.

Pierce, F. J., Larson, W. E., Dowdy, R. H., Graham, \& W. A. P. (1983). Productivity of soil: assessing of long-term changes due to erosion. Journal of Soil and Water Conservation . 38, 39-44.

Quinton, J. N., Govers, G., Van Oost, K., \& Bardgett, R. D. (2010). The impact of agricultural soil erosion on biogeochemical cycling, Nature Geoscienc e, 3, 311-314.

Rejman, J., \& Iglik, I. (2010). Topsoil reduction and cereal yields on loess soils of Southeast Poland. Land Degradation 83 Development , 21, 401-405.

Russo, V. M., Collins, J. K., Perkins-Veazie, P., \& Smith, T. (2004). Carbohydrate distribution in stalks and ears of sweet maize with different endosperm genotypes. Cereal Research Communications , 32, 91-98.

Sanaullah, M., Rumpel, C., Charrier, X., \& Chabbi, A. (2012). How does drought stress influence the decomposition of plant litter with contrasting quality in a grassland ecosystem? Plant and Soil , 352, $277-288$. 
Sarapatka, B., Cap, L., \& Bila, P. (2018). The varying effect of water erosion on chemical and biochemical soil properties in different parts of Chernozem slopes. Geoderma , 314, 20-26.

Shinohara, Y., Otani, S., Kubota, T., Otsuki, K., \& Nanko, K. (2016). Effects of plant roots on the soil erosion rate under simulated rainfall with high kinetic energy. Hydrological Science Journal , 61, 2435-2442.

Srinivasan, V., Maheswarappa, H. P., \& Lal, R. (2012). Long term effects of topsoil depth and amendments on particulate and non particulate carbon fractions in a Miamian soil of Central Ohio.Soil EJTillage Research , 12, 110-117.

Stott, D. E., Andrews, S. S., Liebig, M. A., Wienhold, B. J., \& Karlen, D. I. (2010). Evaluation of $\beta-$ glukosidase activity as a soil quality indicator for the soil management assessment Framework. Soil Science Society of America Journal , 74, 107-119.

Sui, Y. Y., Jiao, X. G., Liu, X. B., Zhang, X. Y., \& Ding, G.W. (2013). Response of soil microbial biomass and enzyme activity to soil fertilization in an eroded farmland of Chinese Mollisols. Communications in Soil Science and Plant Analysis , 44, 2809-2819.

Sui, Y. Y., Liu, X. B., Jin, J., Zhang, S. L., Zhang, X. Y., Herbert, S. J., \& Ding, G. W. (2009). Differentiating the early impacts of topsoil removal and soil amendments on crop performance productivity of corn and soybean in eroded farmland of Chinese Mollisols. Field Crops Research , 111, 276-283.

Wang, B., Xue, S., Liu, G. B., Zhang, G. H., Li, G., \& Ren, Z. P. (2012). Changes in soil nutrient and enzyme activities under different vegetations in the Loess Plateau area, Northwest China. Catena , 92,186-195.

Wang, J., Xie, Y., Liu, G., Zhao, Y., \& Zhang, S. S. (2015). Soybean root development under water stress in eroded soils. Acta Agriculture Scandinavica Section B-Soil and Plant Science, 65, 374-382.

Wang, Z., Sadras, V. O., Hoogmoed, M., Yang, X. Y., Huang, F., Han, X. Y., Zhang, S. L. (2017). Shifts in nitrogen and phosphorus uptake and allocation in response to selection for yield in Chinese winter wheat. Crop E Pasture Science, 68, 807-816.

Wang, Z. Q., Liu, B. Y., Wang, X. Y., Gao, X. F., \& Liu, G. (2009). Erosion effect on the productivity of black soil in Northeast China.Science in China Series D-Earth Sciences , 52, 1005-1021.

Xie, Y., Lin, H. H., Ye, Y., \& Ren, X. Y. (2019). Changes in soil erosion in cropland in northeastern China over the past 300 years. Catena , 176, 410-418.

Xiong, K., Yin, C., \& Ji, H. B. (2018). Soil erosion and chemical weathering in a region with typical karst topography.Environmental Earth Sciences , 77, 500.

Xu, J. M., Liu, T. T., \& Mao, C. Z. (2018). Determination of inorganic phosphate in rice by SKALAR $\mathrm{San}^{++}$continuous flowing analyzer.Analytical Instrumentation , 3, 46-50 (In Chinese).

Zhang, K. L, Shu, A. P., Xu, X. L., Yang, Q. K., \& Yu, B. (2008). Soil erodibility and its estimation for agricultural soils in China. Journal of Arid Environments , 6, 1002-1011.

Zhao, J. L., Van Oost, K., Chen, L. Q., \& Govers, G. (2016). Moderate topsoil erosion rates constrain the magnitude of the erosion-induced carbon sink and agricultural productivity losses on the Chinese Loess Plateau. Biogeosciences, 13, 4735-4750.

Zheng, F. L., He, X. B., Gao, X. T., Zhang, C., \& Tang, K. L. (2005). Effects of erosion patterns on nutrient loss following deforestation on the Loess Plateau of China. Agriculture Ecosystems Environment, $108,85-97$.

Zhou, K. Q., Sui, Y. Y., Liu, X. B., Zhang, X. Y., Jin, J., Wang, G. H., \& Herbert, S. J. (2015). Crop rotation with nine-year continuous cattle manure addition restores farmland productivity of artificially eroded Mollisols in Northeast China. Field Crops Research , 171, 138-145. 
Zöbisch, M. A., Richterby, C., Heiligtag, B., \& Schlott, R. (1995). Nutrient losses from cropland in the Central Highlands of Kenya due to surface runoff and soil erosion. Soil ESTillage Research, 33, 109-116.

Table 1. Significant level $(P)$ of main effects and interactions of topsoil depth and crop species on grain yield $(2016,2017,2018)$, growth parameters (2017), nutrient uptake (2017), and concentrations of available nutrients (N, P and K) and activities of enzymes in the rhizosphere soil (2017) of maize at the jointing (V7) and milk (R3) stages, and of soybean at the initial flowering (R1) and seed-filling (R6) stages.

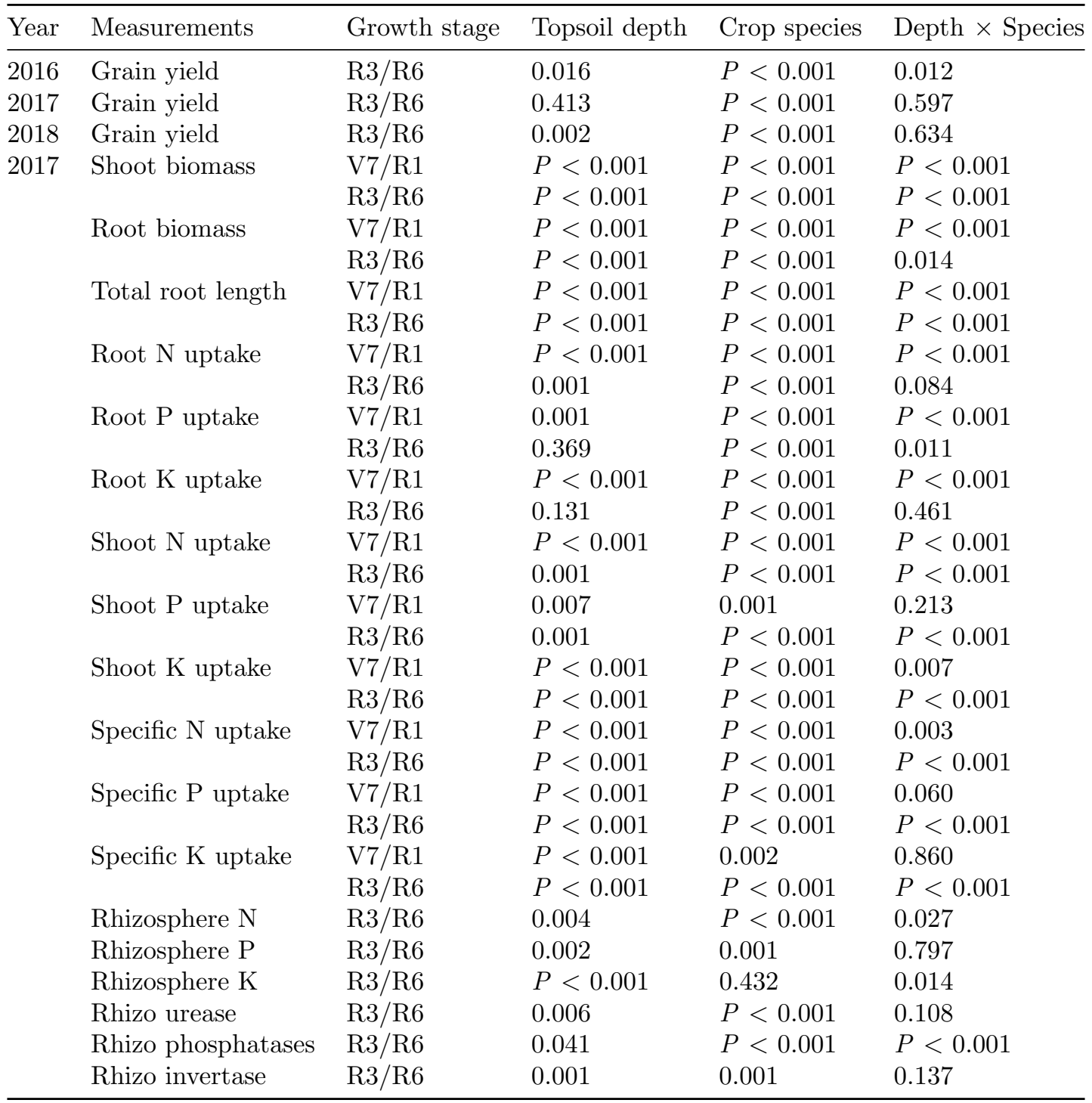



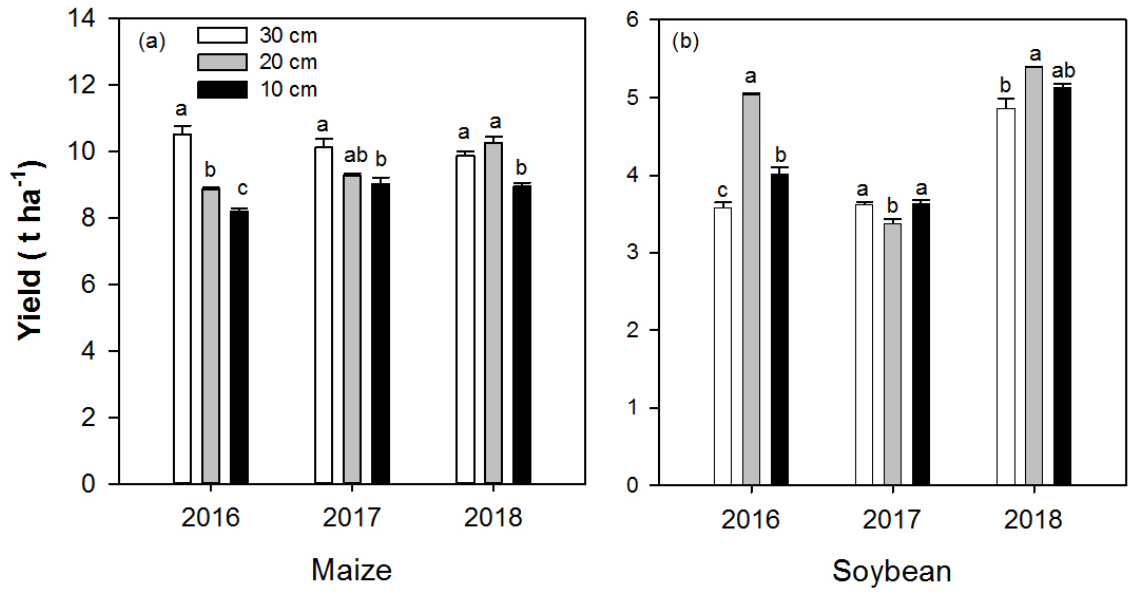

Fig. 1. Effect of topsoil depth on grain yields of maize and soybean in 2016, 2017 and 2018. The main effects of topsoil depth, crop species and cropping year, and their interactions are all highly significant $(P$ $<0.001)$. Values with means \pm standard error $(n=3)$. Within a growing season of each panel, values with a same letter are not significantly different $(P>0.05)$.
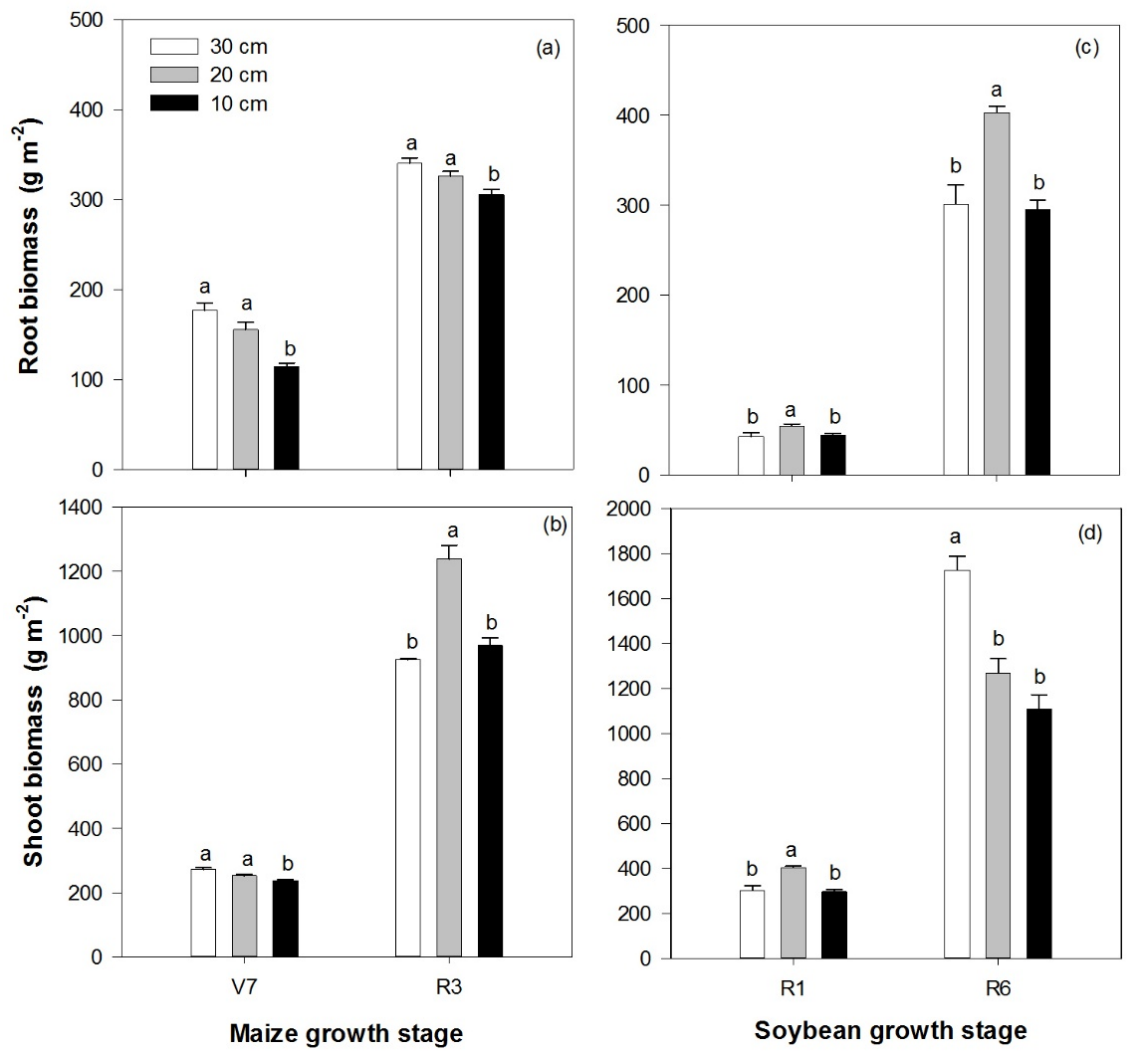

Fig. 2. Effect of reduced topsoil depth on root and shoot biomass of maize at the jointing (V7) and milk (R3) stages, and of soybean at the initial flowering (R1) and seed-filling (R6) stages in 2017. Values with means \pm standard error $(\mathrm{n}=3)$. Within a growth stage of each panel, values with a same letter are not significantly different $(P>0.05)$. 

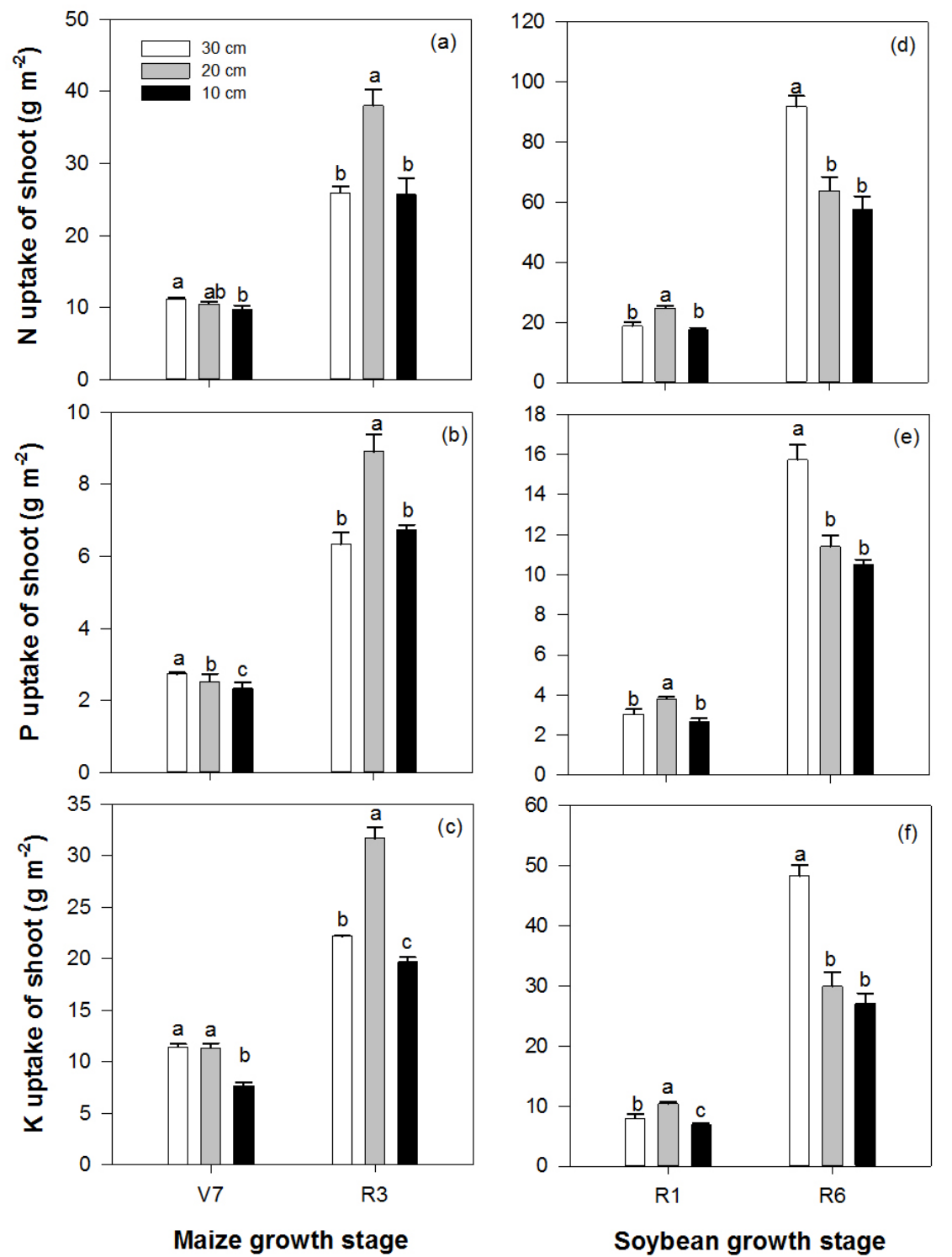

Fig. 3. Effect of topsoil depth on $\mathrm{N}, \mathrm{P}$ and $\mathrm{K}$ uptake in shoot of maize at the jointing (V7) and milk (R3) stages, and of soybean at the initial flowering (R1) and seed-filling (R6) stages in 2017. Values with means \pm standard error $(\mathrm{n}=3)$. Within a growth stage of each panel, values with a same letter are not significantly different at $(P>0.05)$. 

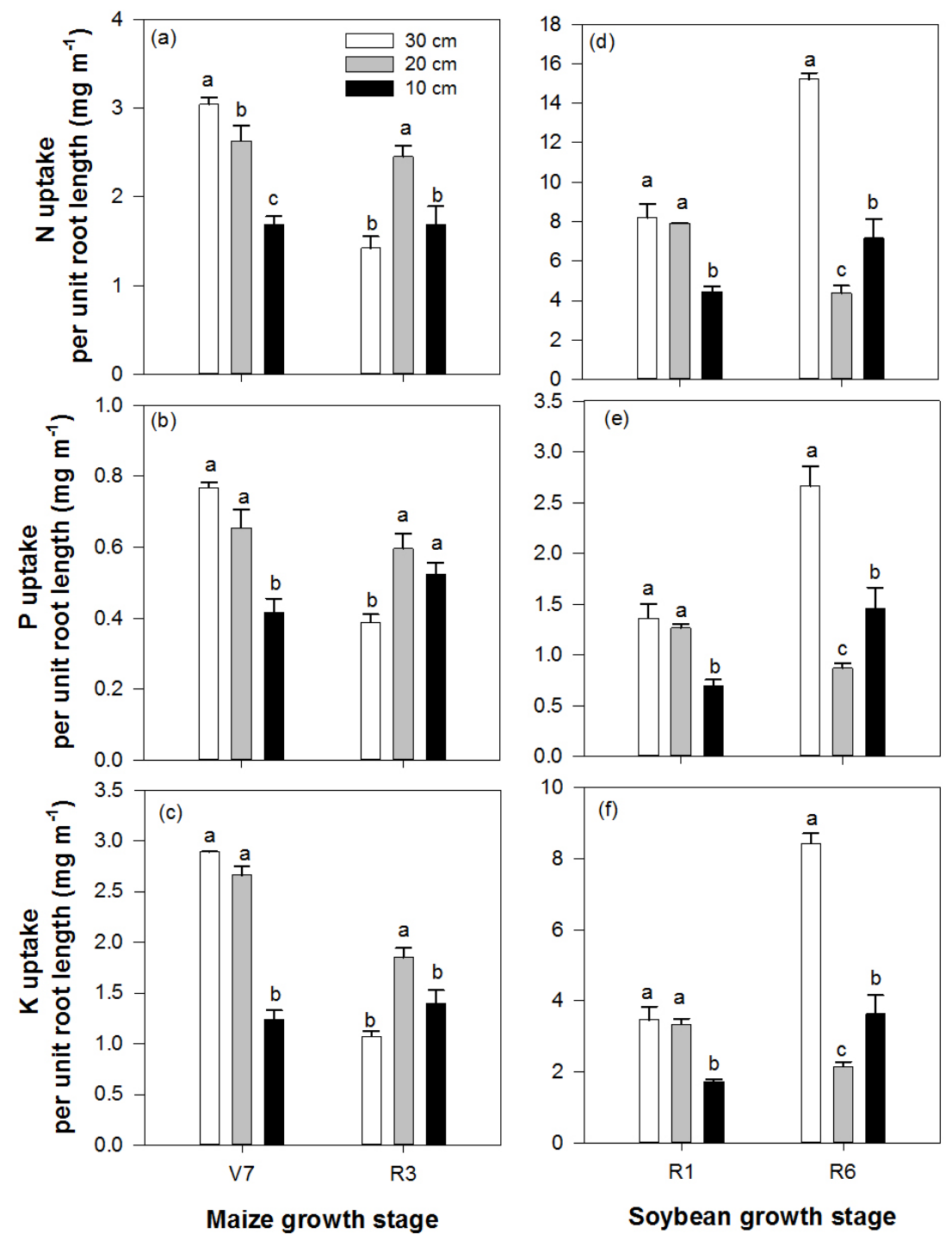

Fig. 4. Effect of topsoil depth on $\mathrm{N}, \mathrm{P}$ and $\mathrm{K}$ uptake per unit root length of maize at the jointing (V7) and milk (R3) stages, and of soybean at the initial flowering (R1) and seed-filling (R6) stages in 2017. Values with means \pm standard error $(\mathrm{n}=3)$. Within a growth stage of each panel, values with a same letter are not significantly different at $(P>0.05)$. 

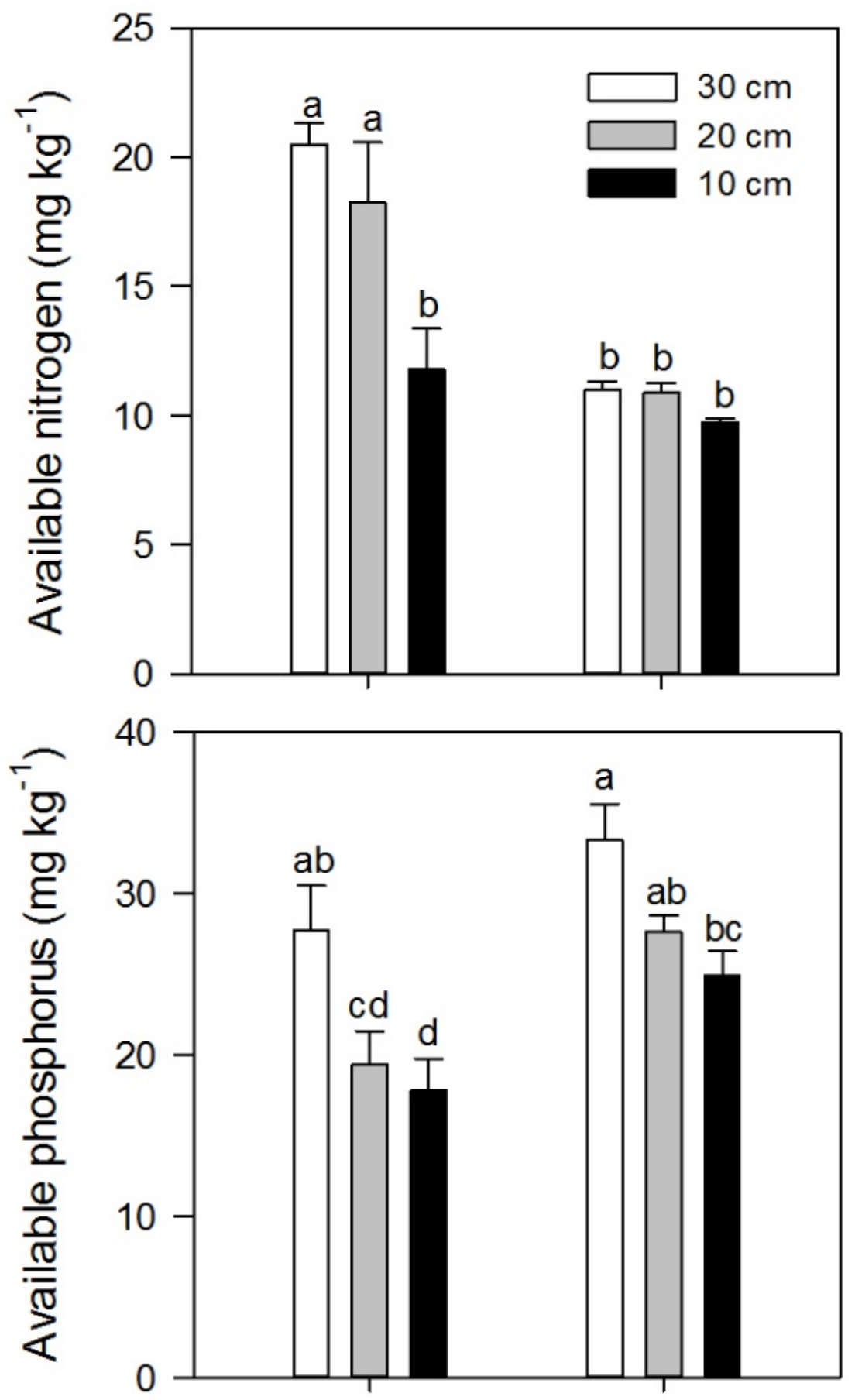

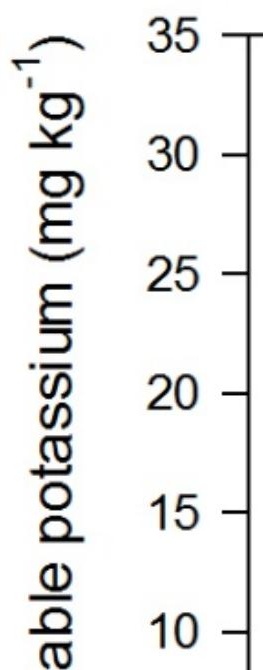


Fig. 5. Effect of topsoil depth on the concentrations of available N, P and K in the rhizosphere soil of maize at the milk stage (R3), and of soybean at the seed-filling stage (R6) in 2017. Values with means \pm standard error $(\mathrm{n}=3)$. Within each panel, values with a same letter are not significantly different at $P>0.05$ among treatments in two crops (2-way ANOVA). 

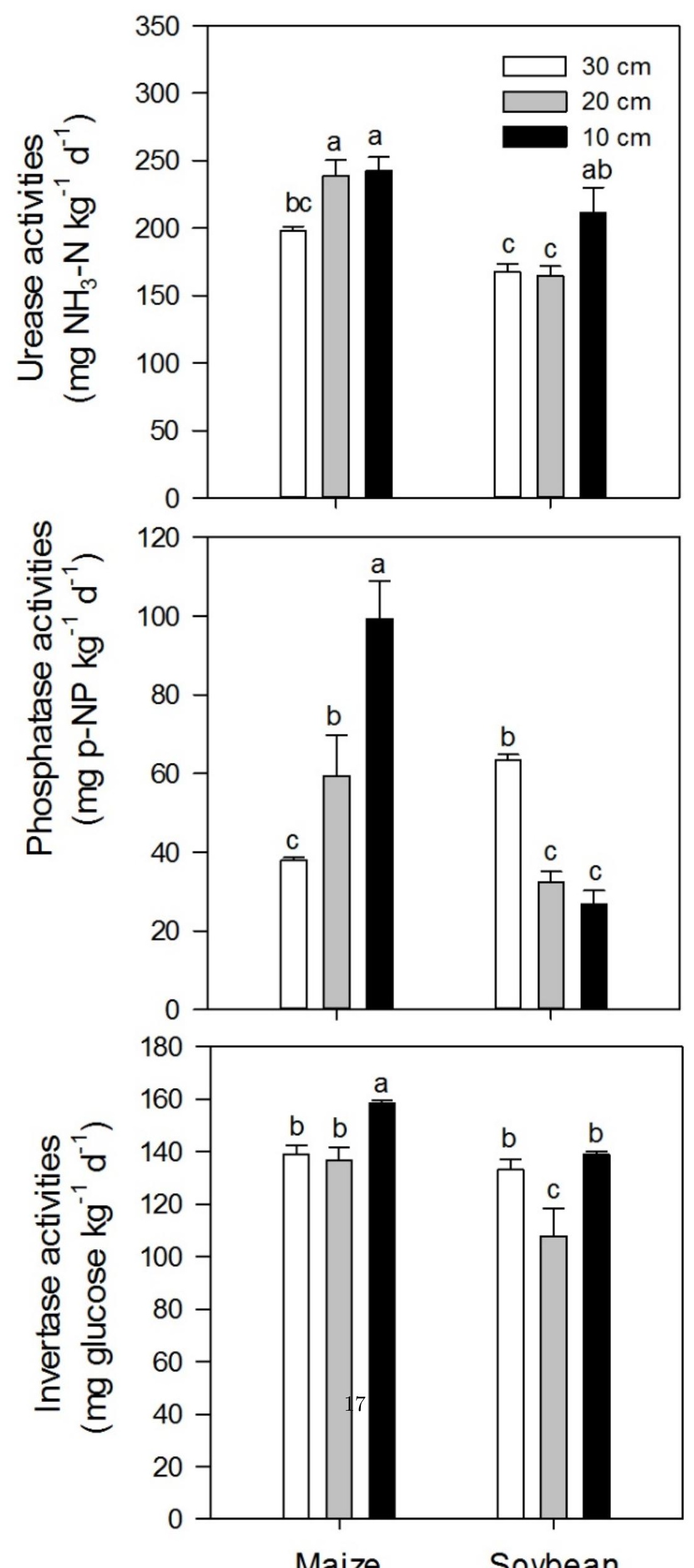
Fig. 6.Effect of topsoil depth on enzyme activities in the rhizosphere of maize at the milk stage (R3), and of soybean at the seed-filling stage (R6) in 2017. Values with means \pm standard error $(n=3)$. Within each panel, values with a same letter are not significantly different at $P>0.05$ among treatments in two crops (2-way ANOVA).

Table S1. The effect of topsoil depth on the concentrations of N, P and K in root, stem and leaves of maize at the jointing (V7) and milk (R3) stages, and of soybean at the initial flowering (R1) and seed-filling (R6) stages in 2017. Values with means \pm standard error $(n=3)$. Values with a same letter are not significantly different between topsoil depths $(P>0.05)$.

\begin{tabular}{llllllll}
\hline Stage & Soil nutrients & Root $\left(\mathrm{g} \mathrm{kg}^{-1}\right)$ & Root $\left(\mathrm{g} \mathrm{kg}^{-1}\right)$ & Root $\left(\mathrm{g} \mathrm{kg}^{-1}\right)$ & Stem $\left(\mathrm{g} \mathrm{kg}^{-1}\right)$ & Stem $\left(\mathrm{g} \mathrm{kg}^{-1}\right)$ & Stem $(\mathrm{g})$ \\
\hline \multirow{3}{*}{2017 Maize } & & $10 \mathrm{~cm}$ & $20 \mathrm{~cm}$ & $30 \mathrm{~cm}$ & $10 \mathrm{~cm}$ & $20 \mathrm{~cm}$ & $30 \mathrm{~cm}$ \\
V7 & 2017 Maize & 2017 Maize & 2017 Maize & 2017 Maize & 2017 Maize & 2017 Maize & 2017 Mai \\
& $\mathrm{N}$ & $15.0 \pm 0.6 \mathrm{a}$ & $13.3 \pm 0.7 \mathrm{a}$ & $14.6 \pm 0.5 \mathrm{a}$ & $16.1 \pm 1.5 \mathrm{a}$ & $16.7 \pm 2.0 \mathrm{a}$ & $16.4 \pm 0.8$ \\
& $\mathrm{P}$ & $4.2 \pm 0.1 \mathrm{a}$ & $3.8 \pm 0.2 \mathrm{a}$ & $4.2 \pm 0.1 \mathrm{a}$ & $5.0 \pm 0.4 \mathrm{a}$ & $5.2 \pm 0.4 \mathrm{a}$ & $5.1 \pm 0.1 \mathrm{a}$ \\
$\mathrm{R} 3$ & $\mathrm{~K}$ & $6.4 \pm 1.4 \mathrm{a}$ & $8.8 \pm 0.4 \mathrm{a}$ & $9.2 \pm 0.4 \mathrm{a}$ & $17.7 \pm 3.8 \mathrm{~b}$ & $26.6 \pm 0.1 \mathrm{a}$ & $24.2 \pm 0.4$ \\
& $\mathrm{~N}$ & $6.4 \pm 0.6 \mathrm{~b}$ & $8.6 \pm 0.4 \mathrm{a}$ & $7.7 \pm 0.7 \mathrm{ab}$ & $5.8 \pm 0.5 \mathrm{a}$ & $7.0 \pm 0.5 \mathrm{a}$ & $6.6 \pm 0.9 \mathrm{a}$ \\
& $\mathrm{P}$ & $3.5 \pm 0.3 \mathrm{a}$ & $3.3 \pm 0.1 \mathrm{a}$ & $3.6 \pm 0.2 \mathrm{a}$ & $2.7 \pm 0.2 \mathrm{a}$ & $2.8 \pm 0.1 \mathrm{a}$ & $2.8 \pm 0.1 \mathrm{a}$ \\
& $\mathrm{K}$ & $6.3 \pm 0.3 \mathrm{a}$ & $6.8 \pm 0.7 \mathrm{a}$ & $6.0 \pm 0.3 \mathrm{a}$ & $10.9 \pm 1.4 \mathrm{a}$ & $14.2 \pm 2.4 \mathrm{a}$ & $12.5 \pm 1.2$ \\
2017 Soybean \\
R1 & 2017 Soybean & 2017 Soybean & 2017 Soybean & 2017 Soybean & 2017 Soybean & 2017 Soybean & 2017 Soy \\
& $\mathrm{N}$ & $14.4 \pm 0.2 \mathrm{a}$ & $14.5 \pm 1.2 \mathrm{a}$ & $14.9 \pm 0.6 \mathrm{a}$ & $13.5 \pm 0.5 \mathrm{a}$ & $15.8 \pm 2.2 \mathrm{a}$ & $15.8 \pm 0.4$ \\
& $\mathrm{P}$ & $4.3 \pm 0.2 \mathrm{a}$ & $4.8 \pm 0.1 \mathrm{a}$ & $4.4 \pm 0.2 \mathrm{a}$ & $3.8 \pm 0.1 \mathrm{a}$ & $3.9 \pm 0.1 \mathrm{a}$ & $4.1 \pm 0.1 \mathrm{a}$ \\
$\mathrm{R} 6$ & $\mathrm{~K}$ & $3.6 \pm 0.4 \mathrm{~b}$ & $6.5 \pm 0.3 \mathrm{a}$ & $5.9 \pm 0.6 \mathrm{a}$ & $13.2 \pm 0.3 \mathrm{a}$ & $14.0 \pm 0.7 \mathrm{a}$ & $14.3 \pm 1.4$ \\
& $\mathrm{~N}$ & $10.6 \pm 0.2 \mathrm{a}$ & $11.5 \pm 0.9 \mathrm{a}$ & $8.2 \pm 0.5 \mathrm{~b}$ & $13.6 \pm 0.9 \mathrm{a}$ & $12.4 \pm 0.7 \mathrm{a}$ & $13.1 \pm 0.1$ \\
& $\mathrm{P}$ & $4.4 \pm 0.4 \mathrm{a}$ & $3.8 \pm 0.1 \mathrm{a}$ & $2.7 \pm 0.2 \mathrm{~b}$ & $4.6 \pm 0.5 \mathrm{a}$ & $4.1 \pm 0.2 \mathrm{a}$ & $4.2 \pm 0.3 \mathrm{a}$ \\
& $\mathrm{K}$ & $2.2 \pm 0.3 \mathrm{~b}$ & $2.9 \pm 0.3 \mathrm{~b}$ & $4.9 \pm 0.6 \mathrm{a}$ & $8.6 \pm 0.1 \mathrm{~b}$ & $7.7 \pm 0.5 \mathrm{~b}$ & $10.8 \pm 0.4$ \\
& & & & & & &
\end{tabular}




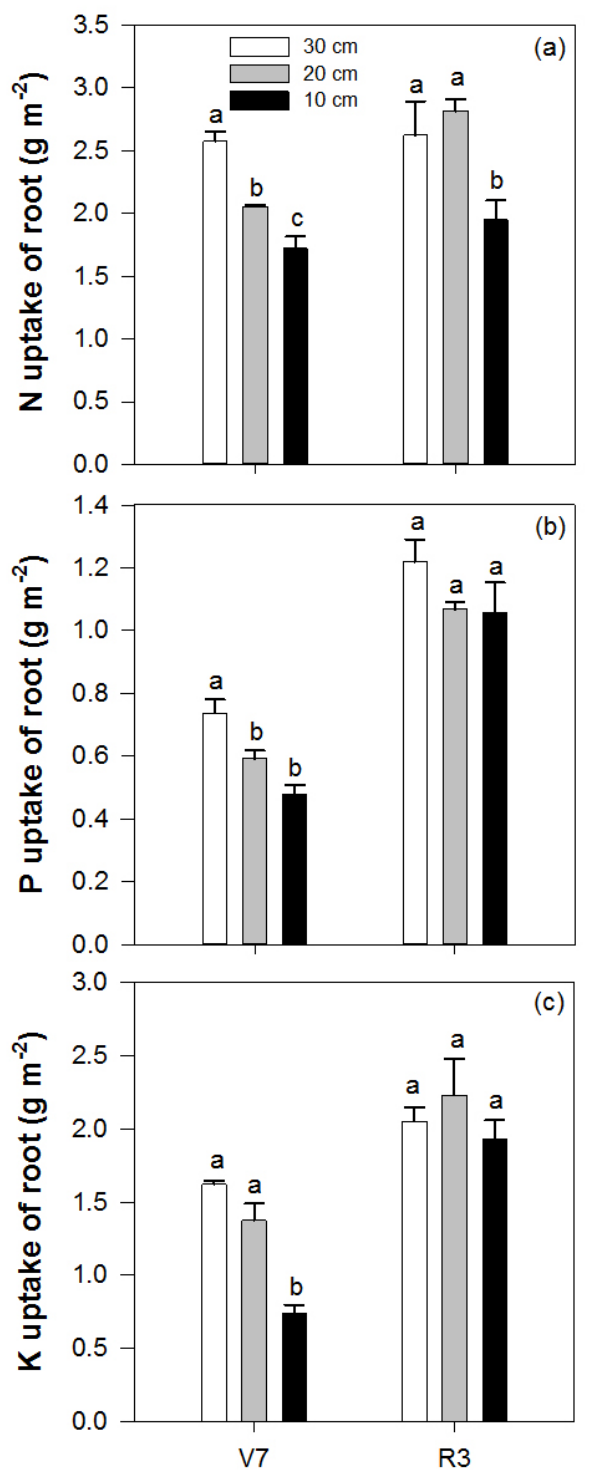

Maize growth stage
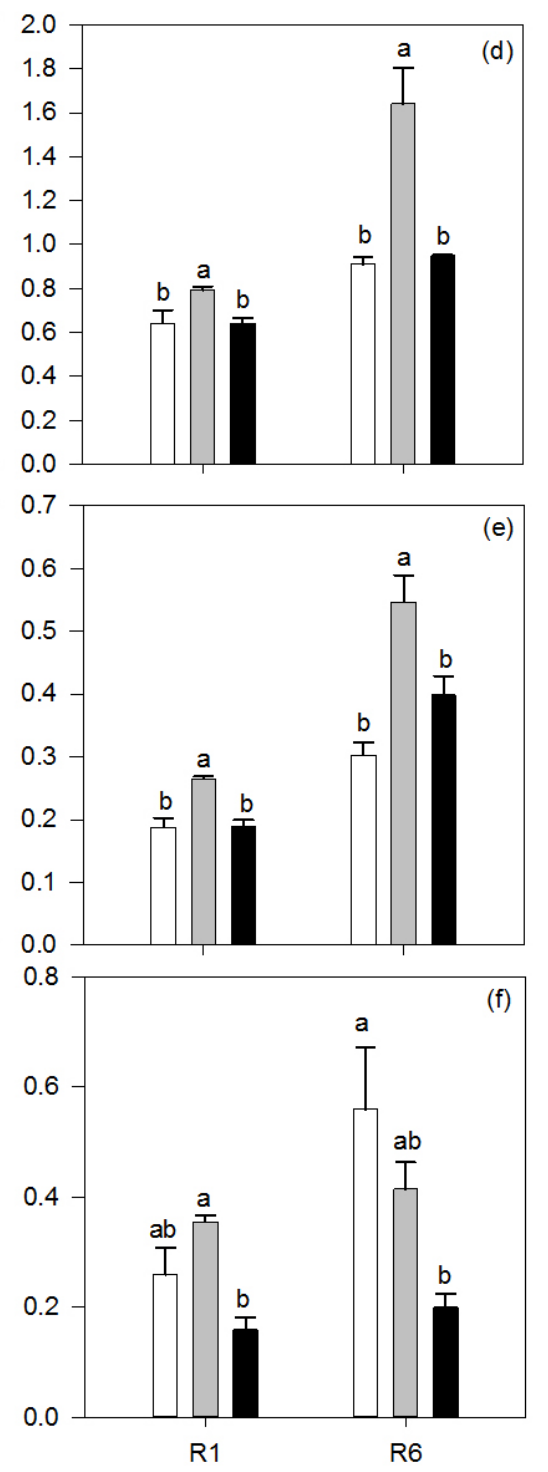

Soybean growth stage

Fig. S1. Effect of topsoil depth on N, P and K uptake in root of maize at the jointing (V7) and milk (R3) stages, and of soybean at the initial flowering (R1) and seed-filling (R6) stages in 2017. Values with means \pm standard error $(\mathrm{n}=3)$. Within a growth stage of each panel, values with a same letter are not significantly different $(P>0.05)$. 

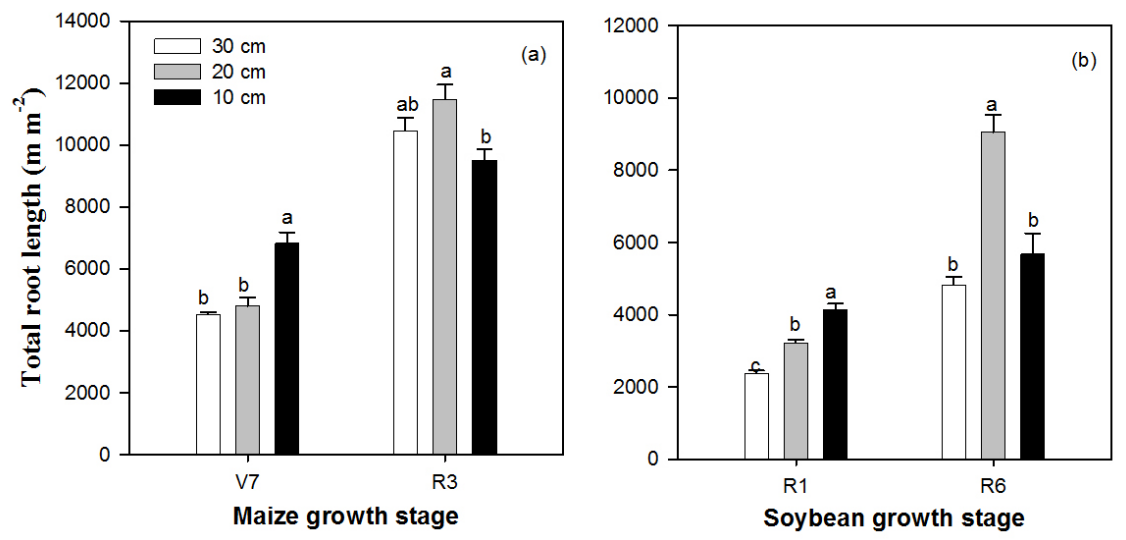

Fig. S2. Effect of topsoil depth on total root length of maize at the jointing (V7) and milk (R3) stages, and of soybean at the initial flowering (R1) and seed-filling (R6) stages in the top $30 \mathrm{~cm}$ of soil profile in 2017. Values with means \pm standard error $(\mathrm{n}=3)$. Within a growth stage of each panel, values with a same letter are not significantly different $(P>0.05)$.
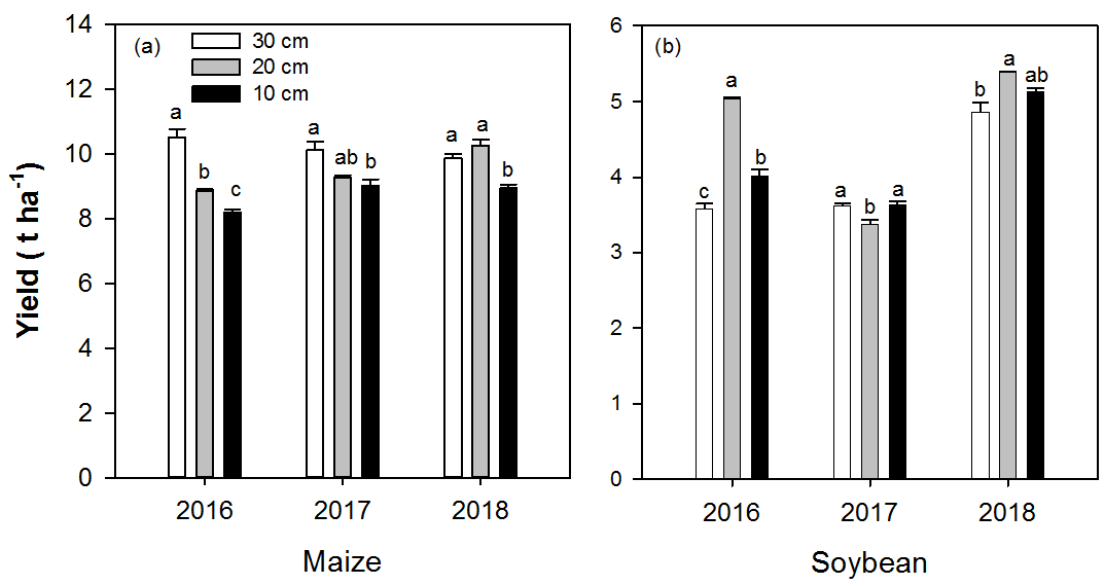

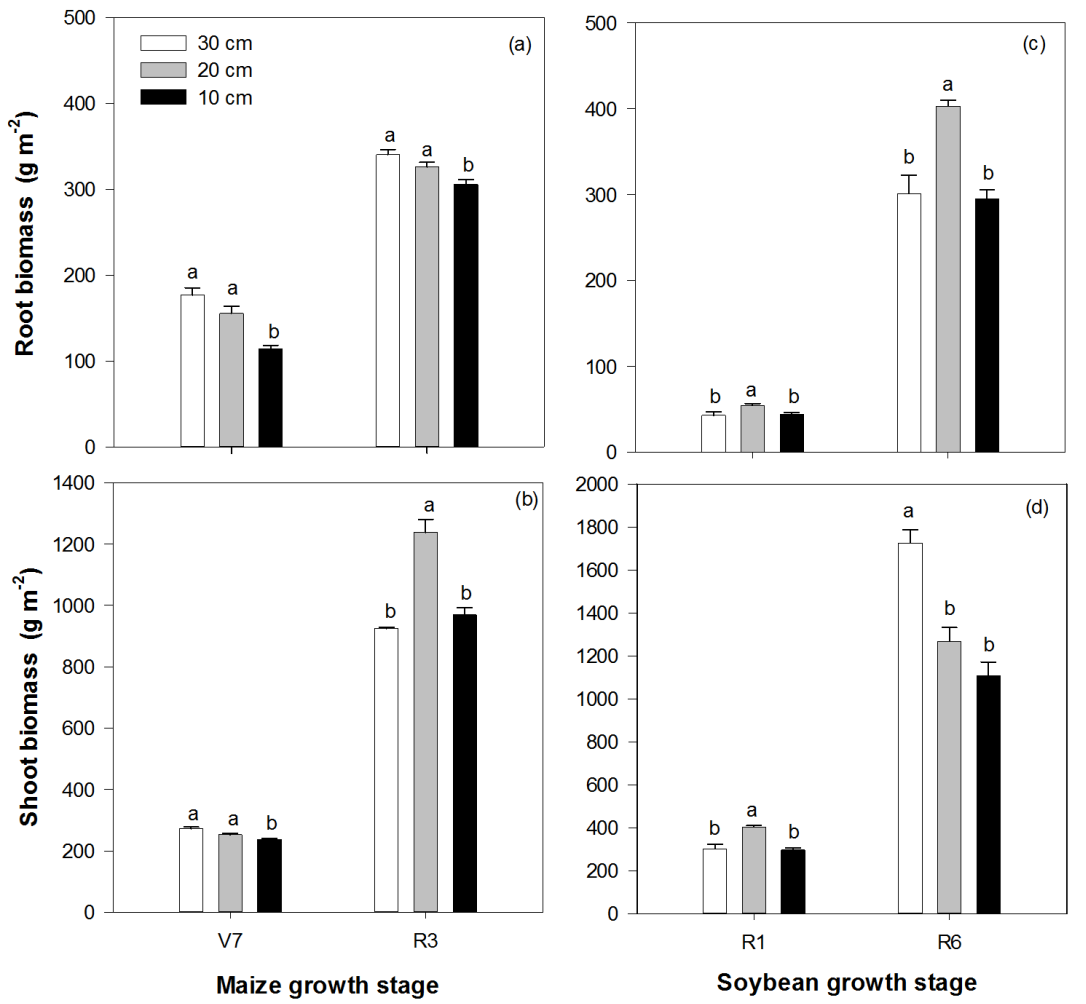

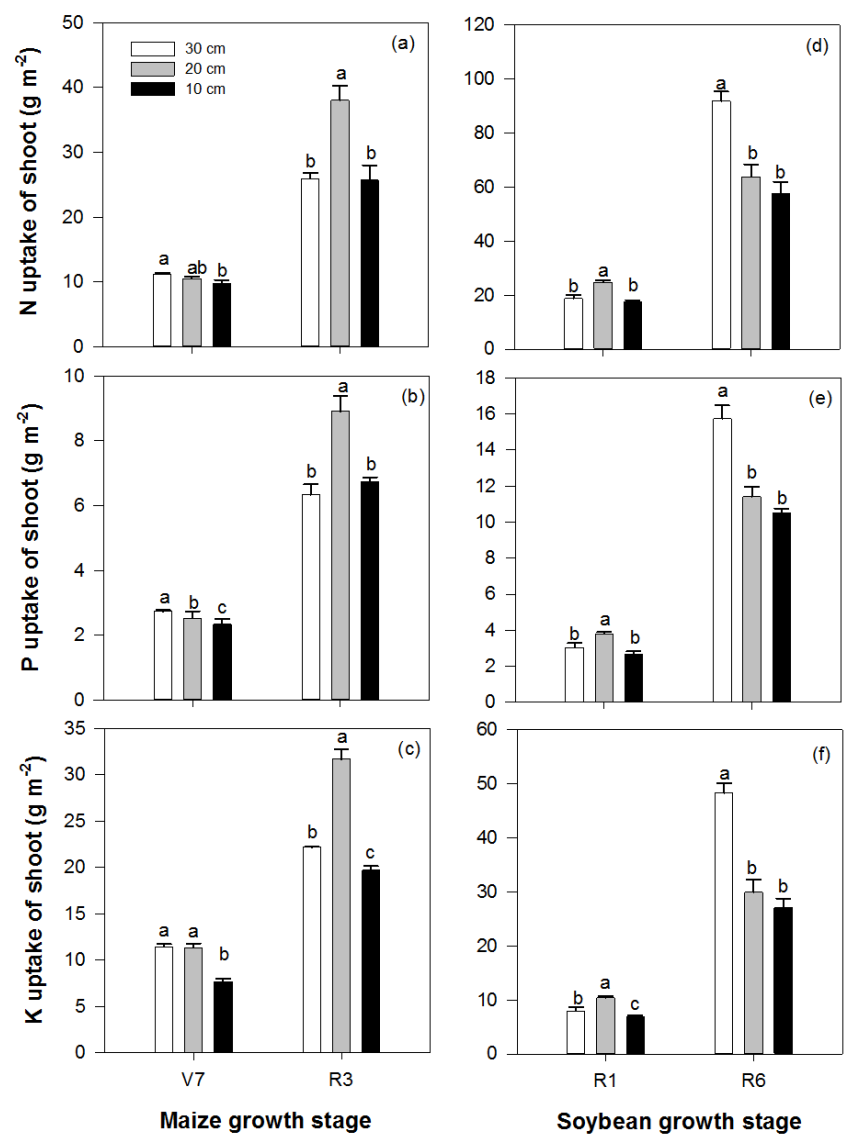

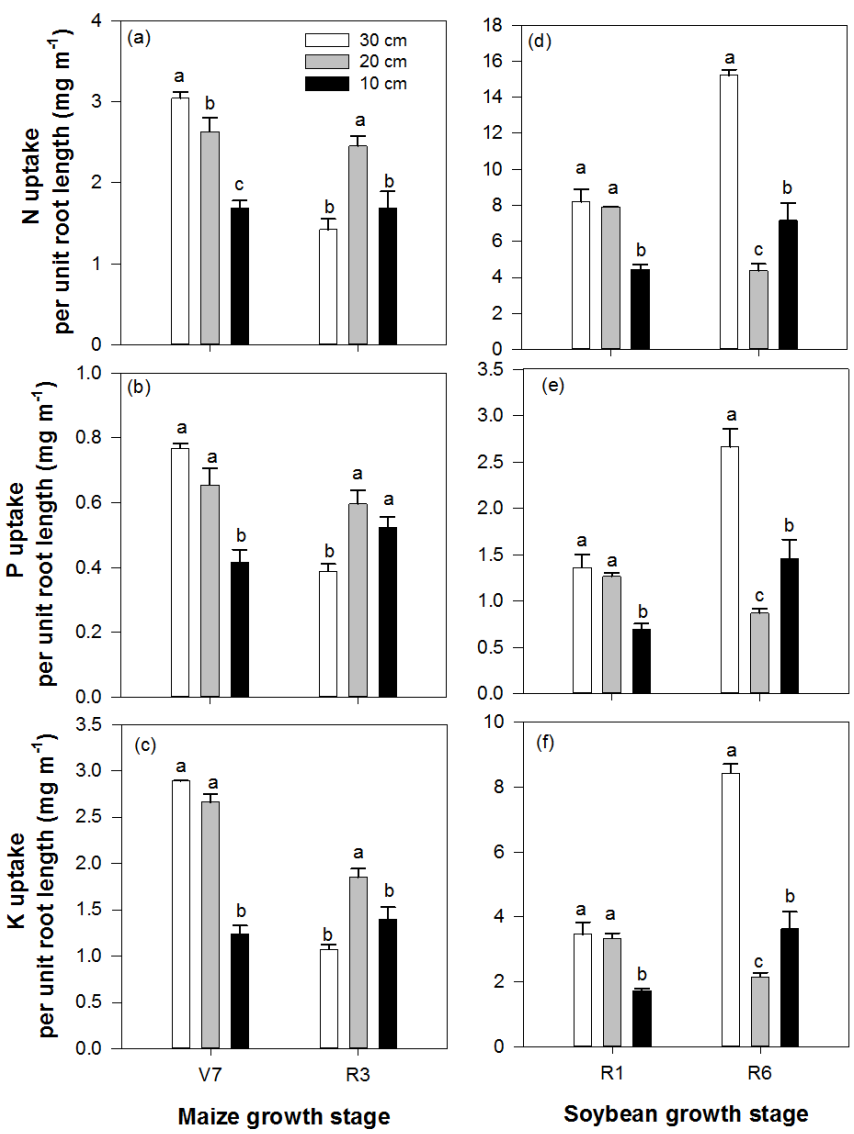

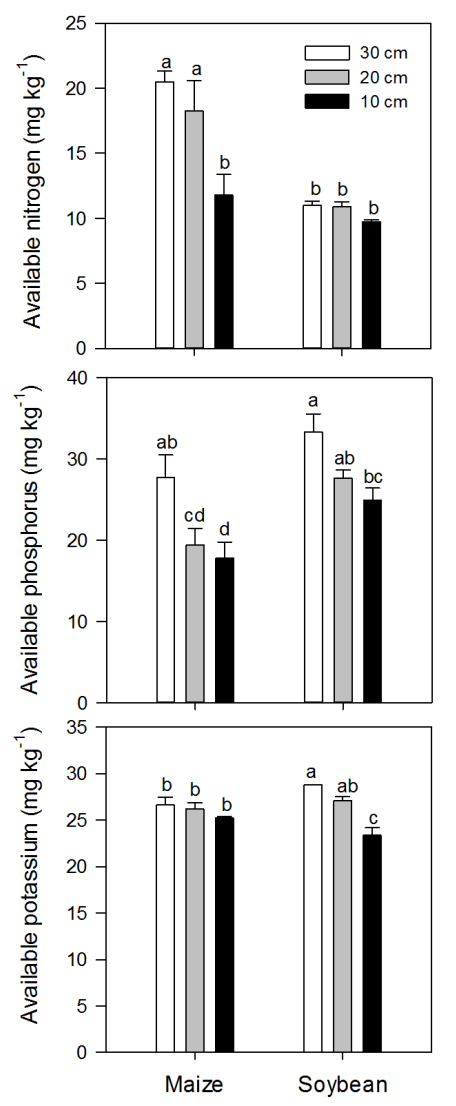


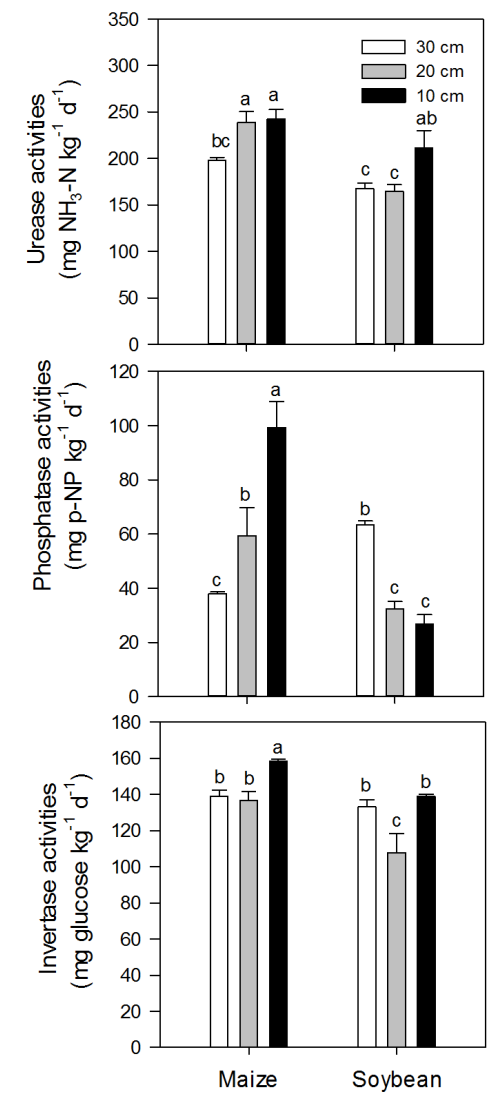

\section{Hosted file}

Table 1.docx available at https://authorea.com/users/323570/articles/452160-erosion-oftopsoil-decreases-the-yield-and-nutrient-uptake-of-maize-and-soybean-grown-in-mollisols 